\title{
REKAYASA KOMPOSIT SANDWICH BERPENGUAT SERAT RAMIE DENGAN CORE SEKAM PADI
}

\author{
Agus Hariyanto \\ Teknik Mesin Universitas Muhammadiyah Surakarta \\ Jl. A.Yani Tromol Pos I Pabelan, Kartosura \\ email : agus_haryanto@ums.ac.id
}

\begin{abstract}
ABSTRAK
Tujuan penelitian ini adalah menyelidiki pengaruh fraksi volume core terhadap peningkatan kekuatan Impak komposit sandwich serat ramie bermatrix Polyester dengan core sekam padi. Mekanisme perpatahan diamati dengan photo makro. Bahan utama penelitian adalah serat ramie, resin unsaturated polyester 157 BQTN, sekam padi. Hardener yang digunakan adalah MEKPO dengan konsentrasi $1 \%$. Komposit dibuat dengan metode cetak tekan (press mold). Komposit sandwich tersusun terdiri dari dua skin (lamina komposit) dengan core ditengahnya. Lamina komposit sebagai skin terdiri dari serat ramie acak. Fraksi volume serat komposit sebagai skin adalah 40\%. Core yang digunakan sekam padi dengan resin Urea Formaldehide (UF181) dengan hardener HU12 sebesar $1 \%$, dengan fraksi volume sekam padi $30 \%$, $40 \%$, dan $50 \%$. Spesimen dan prosedur pengujian impak charpy mengacu pada standart ASTM D 5942. Penampang patahan dilakukan foto makro untuk mengidentifikasi pola kegagalannya. Hasil penelitian ini menunjukkan bahwa penambahan fraksi volume core menurunkan energi serap dan kekuatan impak secara signifikan komposit sandwich. Seiring dengan peningkatan fraksi volume core juga menurunkan energi serap dan kekuatan impak secara signifikan pula.. Mekanisme patahan diawali oleh kegagalan komposit skin bagian tarik, core gagal geser, dan diakhiri oleh kegagalan skin sisi tekan. Pada bagian daerah batas core dan komposit skin menunjukkan adanya kegagalan delaminasi.
\end{abstract}

Kata Kunci: komposit sandwich, kekuatan impak, energi serap, mekanisme patahan.

\section{PENDAHULUAN}

Serat alam telah dicoba untuk menggeser pengunaan serat sintetis, seperti E-Glass, Kevlar49, Carbon/ Graphite, Silicone Carbide, Aluminium Oxide, dan Boron. Walaupun tak sepenuhnya menggeser, namun penggunaan serat alam menggantikan serat sintesis adalah sebuah langkah bijak dalam menyelamatkan kelestarian lingkungan dari limbah yang dibuat dan keterbatasan sumber daya alam yang tidak dapat diperbaharui. Berbagai jenis tanaman serat tum- buh subur di Indonesia, seperti kenaf (hibiscus canabinus). Produksi serat ramie dunia menduduki posisi mencapai 100.000 ton/tahun (Eichorn, 2001). Di Indonesia, serat ramie tersebut biasanya hanya dipakai sebagai bahan karung goni sehingga nilai ekonominya rendah.

Ketersediaan sekam padi sangat berlimpah, namun nilai jualnya sangat murah dengan harga Rp 15/kg- Rp 50/kg (Rahmarestia, 2006). Sifat ringan sekam padi ini selaras dengan filosofi rekayasa bahan komposit, yaitu menghasilkan 
disain ringan. Keberhasilan aplikasi sekam padi ini sebagai material core pada rekayasa bahan komposit diharapkan dapat menggantikan penggunaan bahan core sintetis impor dari luar negeri, seperti core polyurethane foam (PUF) dan core Divynil cell (PVC) (diabgroup).

Hal lain yang ironis adalah masuknya core kayu balsa yang diimpor dari Australia (diabgroup). Padahal, Indonesia sebagai negara tropis menghasilkan aneka bahan hasil pertanian termasuk sekam padi, produksi padi yang mencapai 51,4 juta ton gabah kering giling sekitar 20 $\%$ dari bobot padi adalah sekam padi (Hara, 1986). Inovasi teknologi dengan memanfaatkan bahan alam merupakan langkah bijak menuju kemandirian bangsa yang bertumpu sumber daya alam lokal. Salah satu solusi kreatif terhadap banyaknya material impor yang masuk di Indonesia adalah memberdayakan material alam lokal yang bertumpu pada budaya riset yang berkelanjutan.

Berdasarkan uraian tersebut di atas, maka penggunaan serat ramie dan sekam padi sebagai bahan komposit sandwich merupakan solusi kreatif untuk mendukung perkembangan teknologi komposit yang ramah lingkungan. Penelitian ini bertujuan untuk menyelidiki pengaruh fraksi volume core terhadap peningkatan kekuatan impak komposit sandwich bermatrik Polyester dengan core sekam padi dengan resin Urea Formaldehide (UF181) dan mengidentifikasi Pola kegagalannnya.

\section{TINJAUAN PUSTAKA}

Yanuar, (2002), melakukan pengujian kekuatan bending dan impak pada komposit GFRP 3 layer. Dari hasil pengujian didapatkan bahwa komposit GFRP 3 layer dengan menggunakan serat E-Glass choped strand mats 300 $\mathrm{gr} / \mathrm{m}^{2}$ mempunyai kekuatan bending $18 \%$ lebih besar dari pada dengan menggunakan serat $E$ Glass choped strand mats $450 \mathrm{gr} / \mathrm{m}^{2}$. Komposit GFRP 3 layer dengan menggunakan serat $E$ Glass choped strand mats $450 \mathrm{gr} / \mathrm{m}^{2}$ mempunyai kekuatan impak $46 \%$ lebih besar dari pada dengan menggunakan serat E-Glass choped strand mats $300 \mathrm{gr} / \mathrm{m}^{2}$. Pada pengujian bending, komposit tersebut mengalami kegagalan pada bagian bawah spesimen. Hal ini menunjukkan bahwa kekuatan tarik material komposit GFRP lebih besar dibandingkan kekuatan tekannya.

Wahyanto dan Diharjo (2004) mensubstitusi penggunaan core PUF dan PVC dengan kayu sengon laut (KSL) yang dipotong melintang dan dikenai perlakuan borac 5\%, untuk mengeluarkan glukosa / sari pati kayu agar tahan terhadap serangan hama bubuk dan jamur. Warna kayu berubah dari putih kemerahan menjadi kuning kecoklatan. Pada kadar air rata-rata 5,77 \%, berat jenis kayu adalah $0,3 \mathrm{gr} / \mathrm{cm}^{3}$. Dengan dimensi yang hampir sama, komposit sandwich GFRP dengan core KSL memiliki kekuatan bending $108.87 \mathrm{MPa}$ atau $25.23 \%$ di atas kekuatan bending komposit GFRP sandwich dengan core PVC H 200. Namun, kekuatan impak komposit sandwich inti PVC H 200 lebih tinggi karena core PVC bersifat lebih lentur sehingga lebih tahan terhadap beban impak. Usaha menggeser penggunaan serat gelas dengan serat alam, maka Febriyanto dan Diharjo (2004) meneliti kinerja bending dan impak komposit hibrid sandwich serat kenaf dan gelas dengan inti KSL. Kinerja bending komposit ini (100.44 MPa) lebih rendah 7.74\% di bawah kekuatan komposit sandwich GFRP inti KSL (108.87 MPa). Namun, ketahanan impak komposit hibrid sandwich tersebut lebih tinggi dibanding komposit GFRP sandwich inti KSL, yaitu $0.0628 \mathrm{~J} / \mathrm{mm}^{2}$ dan $0.058 \mathrm{~J} / \mathrm{mm}^{2}$. Salah satu faktor pendukung meningkatnya ketahanan impak ini adalah sifat alam serat kenaf yang lebih lentur/elastis. Pada panel komposit sandwich, penggunaan core KSL potongan membujur mampu meningkatkan kekuatan bending yang sangat tinggi, namun kekuatan impaknya hampir sama dengan potongan melintang. Kelemahan penggunaan core kayu potongan membujur adalah geometri panel dapat berubah (ngulet).

Hillger (1998) mengemukakan bahwa ada beberapa macam tipe kerusakan pada pengujian impak yang dapat dideteksi, seperti :retak dan delaminasi pada skin, debonding antara skin dan core serta kerusakan didalam core.

Luas kerusakan impak pada struktur sandwich dipengaruhi oleh material core dari 
tumpukan laminasi permukaan sandwich, ukuran, massa, kecepatan pendulum dan kemampuan dari komponen sandwich untuk menyerap beban kejut. Pada struktur sandwich dengan core foam delaminasi dapat dideteksi, yaitu daerah yang terimpak, yang berada di antara skin dan core (Gaedke, 2001).

\section{METODE PENELITIAN}

Bahan utama penelitian adalah serat ramie acak dengan density $1,6 \mathrm{gr} / \mathrm{cm}^{3}$, core sekam padi dengan density $0,85 \mathrm{gr} / \mathrm{cm}^{3}$., unsaturated poliester type $157 \mathrm{BQTN}$, hardener MEKPO dengan kadar $1 \%$, dan adhesive epoxy resin dan epoxy hardener dengan rasio 1:1 dengan density $0,5 \mathrm{ml} / \mathrm{cm}^{2}$. Serat ramie yang digunakan tanpa perlakuan. Pembuatan komposit sandwich dilakukan dengan metode press mold. Fraksi volume serat acak komposit (skin) ditentukan $40 \%$, yang dikontrol dengan ketebalan komposit sandwich saat pencetakan.

Komposit sandwich tersusun dari dua lamina komposit (skin) dengan core sekam padi di bagian tengahnya. Lamina komposit (skin) tersusun dari serat ramie acak. Serat ramie yang
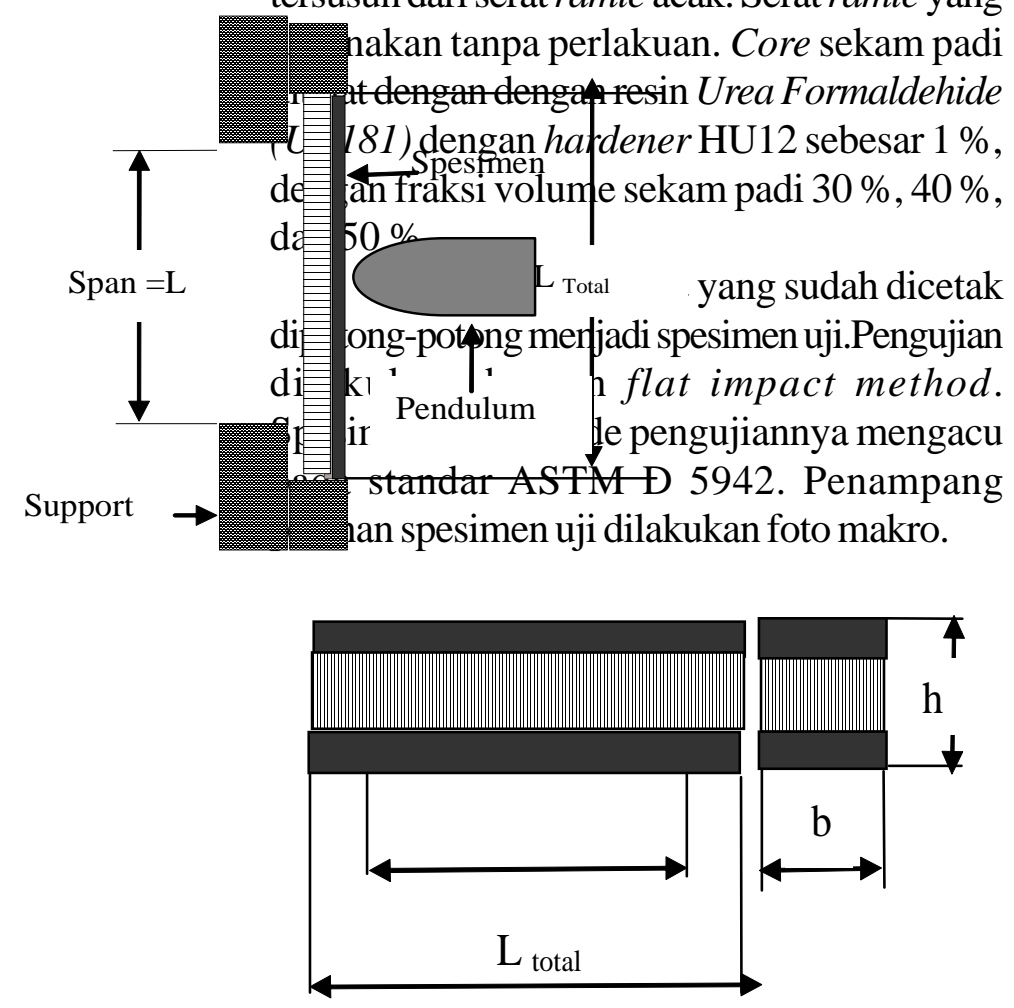

Gambar 1. Spesimen Uji Impak Charpy
Gambar 2. Pemasangan Spesimen

Uji Impak (Flat wise Impact)

Persamaan yang digunakan dalam perhitungan sesuai standar ASTM D 5942 - 96 sandwich sebagai berikut:

$$
\begin{aligned}
& \mathrm{W}=\mathrm{GxR}(\text { cosb-cosa }) \\
& a_{c U}=\frac{W}{h \times b} \times 10^{3}=\frac{W}{h \times b}
\end{aligned}
$$

\section{HASIL DAN PEMBAHASAN}

Tabel 1. Energi Serap Uji Komposit Sandwich.

\begin{tabular}{|c|c|}
\hline $\begin{array}{c}\text { Fraksi Volume } \\
\text { (\%) }\end{array}$ & $\begin{array}{c}\text { Energi Serap } \\
\text { W(Joule) }\end{array}$ \\
\hline 30 & 22.7 \\
\hline 40 & 19.2 \\
\hline 50 & 18.3 \\
\hline
\end{tabular}

Tabel 2. Kekuatan Impak Komposit Sandwich.

\begin{tabular}{|c|c|}
\hline $\begin{array}{c}\text { Fraksi Volume } \\
\mathbf{( \% )}\end{array}$ & $\begin{array}{c}\text { Kekuatan Impak } \\
\mathbf{a}_{\text {cu }}\left(\mathbf{J} / \mathbf{m m}^{\mathbf{2}}\right)\end{array}$ \\
\hline 30 & 104.6 \\
\hline 40 & 88.1 \\
\hline 50 & 84.9 \\
\hline
\end{tabular}


Komposit sandwich yang diperkuat serat ramie acak, dengan core sekam padi, seperti ditunjukkan pada tabel 1 . Pada hal yang sama juga terjadi pada perhitungan kekuatan impak pada tabel 2.

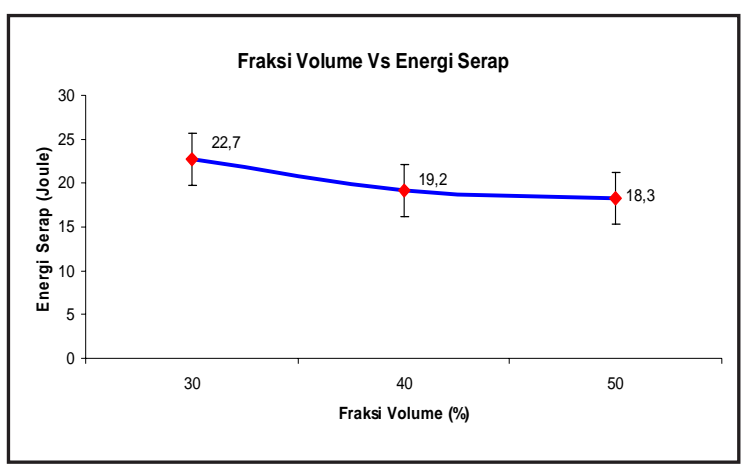

Gambar 3. Energi Serap Uji Impak Komposit Sandwich.

Gambar 4. kekuatan Impak Komposit Sandwich

Dari pengujian impak Charpy, diperoleh kemampuan energi serap komposit sandwich core sekam padi seperti pada gambar 3. Berdasarkan gambar tersebut, energi serap menurun seiring dengan penambahan fraksi volume. Dengan demikian, penambahan bagian inti struktur sandwich menunjukkan secara signifikan penurunan kemampuan menyerap energi impak. Sifat material yang lebih lunak (sekam padi) dan penambahan fraksi volume menyebabkan memiliki kemampuanmenyerap energi yang lebih rendah.

Bila ditinjau dari segi kekuatan impak, penambahan fraksi volume core menurunkan kekuatan impak komposit sandwich. Kekuatan impak komposit sandwich yang diperkuat serat ramie acak dengan core sekam padi memiliki sifat keuletan bahan ini dapat dikatakan lebih baik.

\section{Penampang Patahan}

Gambar 5. Permukaan Patah Komposit Sandwich, Core Sekam Padi pada $\mathrm{V}_{\mathrm{f}}=30 \%$

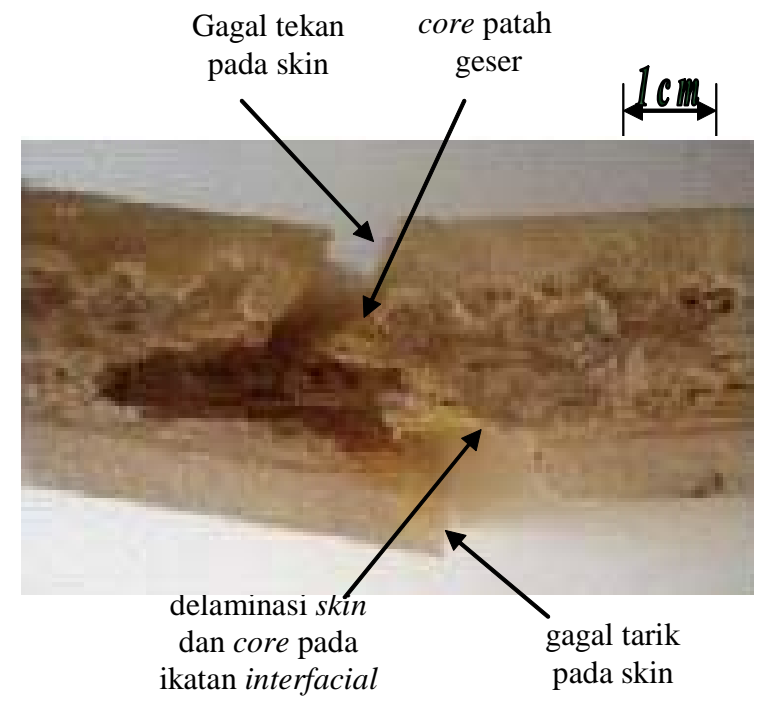

Gambar 6. Permukaan Patah Komposit Sandwich, Core Sekam Padi pada $\mathrm{V}_{\mathrm{f}}=40 \%$ 


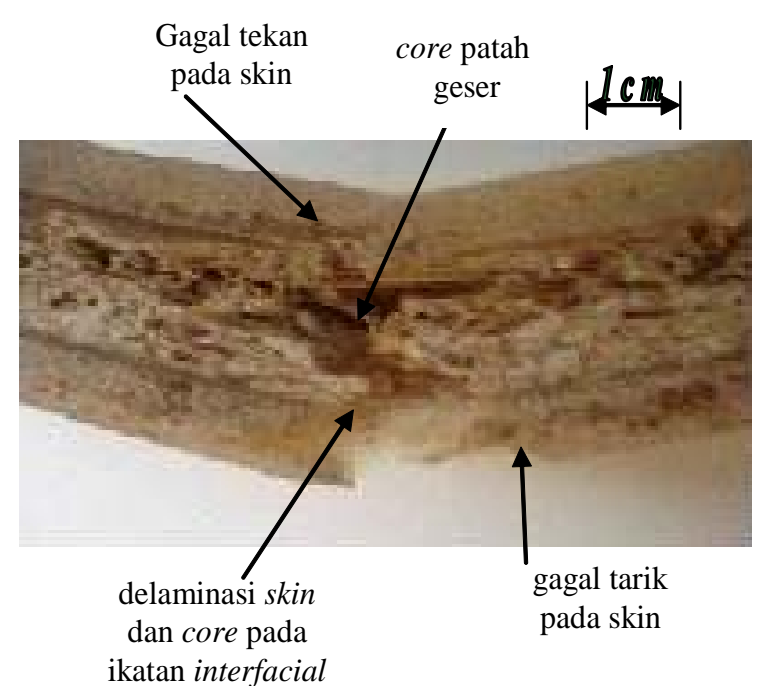

Gambar 7. Permukaan Patah Komposit Sandwich, Core Sekam Padi pada $\mathrm{V}_{\mathrm{f}}=50 \%$

Kegagalan impak komposit sandwich core sekam padi pada $\mathrm{V}_{\mathrm{f}}=30 \%, \mathrm{~V}_{\mathrm{f}}=40 \%$, dan $\mathrm{V}_{\mathrm{f}}=50 \%$ dapat dilihat dalam gambar 5, 6, dan 7. Kegagalan ini umumnya diawali dengan retakan pada komposit skin yang menderita tegangan tarik. Kemudian, beban impak tersebut didistribusikan pada core sehingga menyebabkan core mengalami kegagalan. Skin yang semula menderita beban tekan akhirnya mengalami kegagalan seiring dengan gagalnya core.

Dari spesimen uji mengalami kegagalan tekan pada komposit skin atas, patah geser core dan kegagalan tekan pada kedua skin. Meka- nisme patahan terjadi karena kegagalan komposit sandwich akibat beban impak berawal dari skin komposit sisi belakang dan dilanjutkan dengan kegagalan core, delaminasi skin dan core pada ikatan interfacial.

\section{KESIMPULAN}

Berdasarkan data hasil penelitian tersebut maka dapat disimpulkan sebagai berikut:

1. Efek penambahan fraksi volume core menurunkan energi serap dan kekuatan impak secara signifikan pada komposit

$\beta$ sandwich.

2. Mekanisme patahan akibat beban impak diawali oleh kegagalan komposit skin bagian tarik, core gagal geser, dan diakhiri oleh kegagalan skin sisi tekan. Pada bagian daerah batas core dan komposit skin menunjukkan adanya kegagalan delaminasi pada ikatan interfacial..

\section{NOTASI PERSAMAAN}

$\mathrm{W}=$ Energi patah/serap $(\mathrm{J})$

$\mathrm{G}=$ Berat pendulum $(\mathrm{N})$

$\mathrm{R}=$ Jarak pendulum ke pusat rotasi $(\mathrm{m})$

$=$ Sudut pendulum setelah menabrak benda uji $\left({ }^{\circ}\right)$

$=$ Sudut pendulum tanpa benda uji $\left({ }^{\circ}\right)$

$=$ Kekuatan impak $\left(\mathrm{J} / \mathrm{mm}^{2}\right)$

$\mathrm{h} \quad=$ Tebal specimen $(\mathrm{mm})$

$\mathrm{b} \quad=$ Lebar specimen $(\mathrm{mm})$

\section{DAFTAR PUSTAKA}

Annual Book of Standards, Section 8, D 5942-96, "Standard Test Methods forDetermining Charpy Impact Strength of Plastics" ", ASTM, 1996.

Anonim, 2001,Technical data Sheet ,PT Justus Sakti Raya Corporation, Jakarta.

Anonim, www.diabgroup.com, DIAB manufactures and markets products and services based on advanced polymer and composite technologies, Head OfficeDIAB AB Box 201S31222 LAHOLM Sweden.

Eichorn, S.J., Zafeiropoulus, C.A.B.N., Ansel, L.Y.M.M.P., Entwistle, K.M., Escamilla, P.J.H.F.G.C., Groom,L, Hill, M.H.C., Rials, T.G. and Wild, P.M., 2001, Review Current International 
Research into Cellulosic Fibers and Composites, Journal of Materials Science, Vol. 36, pp. 2107-2131.

Febrianto, B. dan Diharjo, K., 2004, Kekuatan Bending Dan Impak Komposit Hibrid Sandwich Kombinasi Serat Karung Goni Dan Serat Gelas Polyester Dengan Core Kayu Sengon Laut, Skripsi, UNS, Surakarta.

Gaedke, M, 2001, Impact Behavior and Residual Strength of Sandwich Structual Elements Under Static and Fatique Loading, American Institute of Aeronautics and Astronautics, Germany.

Hara, et-all, 1986, “Utilization of Agrowastes for Buildinng Materials”, International Research and Development Cooperation Division, AIST, MITI, Japan.

Hillger, 2003, Inspection of CFRP and GFRP Sandwich Components, Wilhelm Raabe Weg 13, D-3 8110 Braunschweig.

Rahmarestia, dkk., 2006. “Analisis Penggunaan Sumber Energi Biomassa di Bidang Pertanian” Balai Besar Pengembangan Mekanisasi Pertanian, litbang, deptan, Jakarta.

Wahyanto, B. dan Diharjo, K., 2004, Karakterisasi Uji Bending Dan Impak Komposit Sandwich GRFP Dengan Core Kayu Sengon Laut, Skripsi, UNS, Surakarta.

Yanuar, D, 2002, Pengaruh Berat Serat Chooped Strand Terhadap Kekuatan Bending, Impak dan Tarik Komposit GFRP, UNS, Surakarta. 